\title{
The Impact of Student Reading and Reading Habits on Their Reading Performance
}

\author{
Betria Sani ${ }^{1 *}$ \\ ${ }^{1}$ Universitas PGRI Palembang \\ *Corresponding author. Email: betriasani33@gmail.com
}

\begin{abstract}
This study seeks to explore how: (1) students' interest in reading understanding is influenced, (2) the students' habit of reading understanding, and (3) their interest in reading and habits of reading the students' understanding of reading. This thesis is an ex post-facto study that contains two different variables and one dependent. There were 7th grade students in the population. The study consisted of 70 students. The data were gathered by reading questionnaires and reading habits, and by reading understanding tests. Prior to analyzing multiple linear regressions, a necessary study was performed. On the basis of a regression analysis, read interest can be concluded that the student's ability to read the achievement of understanding $(\mathrm{p}=0.04, \mathrm{p}<0.05)$ influences reading habit and understanding capacity $(\mathrm{p}=0.000, \mathrm{p}=$ 0.05 ) of the student, while reading interest and read habit have an impact on the students' ability to read understanding (R2-000, f-count). The result was that if students are keen to learn, they would quickly understand and understand the text.
\end{abstract}

Keywords: Influence, Reading Interest, Reading Habit, Reading Comprehension Achievement

\section{INTRODUCTION}

The learning of English has four language abilities: listen, voice, read and write. Reading is one of the main skills students have understood and have mastered English well. Reading is also including in receptive skills besides listening. Receptive skill is how individuals receiving information because the learned do not need to produce language, they receive and understand. The students must understand the text in order for the reading to provide detailed details from the text. Learning to read and write is a basic ability that not all children in the world have learned enough, sadly [1]. The goal is to train students early on to "learn how to learn" and to bring these skills to other areas of their lives so that they can be independent researchers and users of knowledge throughout their lives [2]. Learning styles are seen as one of the main influences influencing the way students learn. In addition, it is prone to align student education with the "teaching types" of the teachers concerned [3].

In the acquisition of higher-level readers, interest plays a crucial role. The students will achieve a high and low interest rate by assessing the interests of individual students in specific topics and by creating reading comprehension. Determining the results, the interest of higher skills readers in passage issues was dramatically affected. They cannot have the middle or lower ability in reading interest. Instead of reading, leisure time interests increasingly focus on technology and social media [4]. Consequently, the teacher should help her students increase their reading interest to maintain their determination and enthusiasm. Students must only have expertise in reading and writing but must also master all their basic language skills to engage in society [5].

In addition to reading importance, the key point which influences student understanding of reading is the reading habits. Understanding is the mind's ability to interpret and comprehend the force, action and method of learning through understanding, intelligence and understanding through an understanding of abstract concepts. The ability to comprehend a text is primarily crucial to be improved so that students can get the message, data, and aim of a text in written form. If students have comprehended, they would have been able to make many texts as complete as what they have read. Reading habits have been singled out to immensely affect the scholarly output of the students [6];[7];[8]. If students have strong reading practices, their fundamental thinking abilities can be increased and finally academic results can be improved [9].

Based on the writer's experience and observation in teaching reading comprehension at SMP Negeri $32 \mathrm{OKU}$, The author observed that her students had already 
inadequate understanding of reading, low reading understanding and difficulty with reading content. Their ability to read was poor. The students are not interested in reading text which is used because the writer finds some students difficulties in reading. First, the students lack interesting in reading activities. Secondly, students find it hard to read English; obtain general knowledge, the basic information and principal idea of the paragraph in the book. Certain aspects make it impossible for students to read: the students lack vocabulary, the student's prior knowledge, the student interesting in reading English text, and the students knowledge of sentence structure. The students feel bored in the teacher's way of the teaching-learning process. It makes the students get low scores to change the strategy of teaching to solve this problem. The students are said low interest because they once in a while visit the library to reading a book.

Based on the preliminary research which was done by the research in her class, there are two factors that make the students' ability in reading comprehension is low, the first factor is from the students themselves that are students' reading interest. The students are not interested in reading English books, such as scientific books, storybooks, magazines, or newspapers, they also feel hesitant to read English books, they feel difficult to read English books. The second factor is that students have difficulties in comprehending the text, they just read the text without getting the point from the text, so they can not get the meaning of the text easily, and they feel difficulty in getting ideas and messages from the text.

\section{METHODS}

This study conducted a questionnaire and test in order to learn the importance of students in reading, reading habits and reading understanding. Thus, the subjects were never treated or experimented in any way. The investigator first gave the questionnaire and then a reading understanding test. The data obtained from the

questionnaire and evaluation were then analysed to see whether the student's reading interest and habit play a major part in the student's reading understanding. In an analysis of the study results, the investigator used the quantitative approach. The approach was used to find an effect on students' understanding of reading motivation and habits. This study was quantitative with an interpretation of regression, so $\mathrm{X}_{1}, \mathrm{X} 2$, and $\mathrm{Y}$ were analyzed for regression. In order to explain and quantify the impact among students' interest in reading, students' reading habits on their understanding of reading, the investigator shall use the multilinear regression by means of the SPSS 16 Windows programme.

In the first step, students' interest in reading and interests are assessed by means of a questionnaire and, secondly, the student's comprehension of the reading. In most regression analyses, the researcher then conducts a regression analysis between the three variables using questionnaire data and tests.

This study was carried out in the academic year 2020/2021 on the SMP Negeri 32 students at Ogan Komering Ulu. The data of interest in reading was obtained by means of a questionnaire administered on Monday 16 November 2020. The data on reading habits were obtained using a Tuesday questionnaire, November 17th, 2020, and the data of reading comprehension were obtained through a multiple choice test done on Wednesday, November 18th, 2020.

\section{RESULTS AND DISCUSSION}

To measure the students' reading interest, the researcher distributed the questionnaires consisted of 25 items in the Likert Scale form. Siregar [10], stated that to calculate the amount of class use $\mathrm{K}=1+3.3 \log \mathrm{n}$, to calculate the lenght of class use the highest score take away the lowest score divided by the amount score of class.

Table 1. Score of Students' Reading Interest Questionnaire Summary

\begin{tabular}{|r|l|l|l|}
\hline No & $\begin{array}{l}\text { Interval } \\
\text { Score }\end{array}$ & Frequency & Percentage \\
\hline 1 & $58-64$ & 6 & $8.57 \%$ \\
\hline 2 & $65-71$ & 9 & $12.85 \%$ \\
\hline 3 & $72-78$ & 16 & $22.85 \%$ \\
\hline 4 & $79-85$ & 18 & $25.71 \%$ \\
\hline 5 & $86-92$ & 10 & $14.28 \%$ \\
\hline 6 & $93-99$ & 11 & $15.71 \%$ \\
\hline & Total & 70 & $100 \%$ \\
\hline
\end{tabular}

Based on the table above, there were $8.57 \%$ or 6 students who got interval score of $58-64,12,85 \%$ or 9 students who got interval score of $6-71,22.85 \%$ or 16 students who got interval score of $72-78,25.71 \%$ or 18 students who got interval score of $79-85,14.28 \%$ or 10 students who got interval score of $86-92$, and $15.71 \%$ or 11 students who got interval score $93-99$, and $12.85 \%$ or 9 students who got interval score of 94-99 in reading interest. 
Table 2. Descriptive Statistics of Students' Reading Interest

\begin{tabular}{|l|l|}
\hline \multicolumn{1}{|c|}{ Statistics } & Result Reading Interest \\
\hline N $\quad$ Valid & 70 \\
\multicolumn{1}{|c|}{ Missing } & 0 \\
Mean & 79.5571 \\
Std. Error of Mean & 1.24439 \\
Median & 80.0000 \\
Mode & 70.00 \\
Std. Deviation & 10.41130 \\
Variance & 108.395 \\
Range & 40.00 \\
Minimum & 58.00 \\
Maximum & 98.00 \\
Sum & 5569.00 \\
\hline
\end{tabular}

Using the SPSS 16 Windows software, researchers then analyzed the data after the frequency of student interest. The researcher found that mean score of reading interest was 79.55 , Median was 80.00 . Thus, mode was
70, Standard Deviation was 10.411, Variance was 108.395, the range was 40, and the Minimum score that student got was 58, Maximum score that students got was 98.

Table 3. Scores of Students' Reading Habit Qustionnaire Summary

\begin{tabular}{|r|r|r|r|}
\hline \multicolumn{1}{|c|}{ No } & Interval Score & Frequency & Percentage \\
\hline 1 & $58-64$ & 6 & $8.57 \%$ \\
\hline 2 & $65-71$ & 3 & $4.28 \%$ \\
\hline 3 & $72-78$ & 9 & $12.85 \%$ \\
\hline 4 & $79-85$ & 27 & $38.57 \%$ \\
\hline 5 & $86-92$ & 13 & $18.57 \%$ \\
\hline 6 & $93-99$ & 12 & $17.47 \%$ \\
\hline & Total & 70 & $100 \%$ \\
\hline
\end{tabular}

The researcher distributed quetionnaire consisting of 25 items as Linkert Scale in the measurement of student reading habits. that were $8,75 \%$ or 6 students who got interval score of $58-64,4.28 \%$ or 3 students who got interval score of $6-71,12.85 \%$ or 9 students who got interval score of $72-78,38.57 \%$ or 27 students who got interval score of $79-85,18.57 \%$ or 13 students who got interval score of $86-92$, and $17,47 \%$ or 12 students who got interval score of $88-93$, and $11.42 \%$ or 8 students who got interval score of 93-99 in reading habit. 
Table 4. Descriptive Statistics of Students' Reading Habit

\begin{tabular}{|c|c|}
\hline Statistics & Result Reading Habit \\
\hline Valid & 70 \\
\hline Missing & 0 \\
\hline Mean & 81.6714 \\
\hline Std. Error of Mear & 1.16020 \\
\hline Median & 82.0000 \\
\hline Mode & 80.00 \\
\hline Std. Deviation & 9.70689 \\
\hline Variance & 94.224 \\
\hline Range & 40.00 \\
\hline Minimum & 58.00 \\
\hline Maximum & 98.00 \\
\hline Sum & 5717.00 \\
\hline
\end{tabular}

After getting the frequency of students' reading habit, the researcher analyzed the data by using SPSS 16 Program for Windows. the researcher got that the mean score of reading habit was 81.73 , Median was 82.00,
Mode was 80. Thus, Variance that was gotten was 94,548, Range score was 40, Standard Deviation was 9.724. The minimum score that students got was 58 , and maximum score that students got was 98 .

Table 5. Score of Students' Reading Comprehension Test Summary

\begin{tabular}{|l|l|l|l|}
\hline No & $\begin{array}{l}\text { Interval } \\
\text { Score }\end{array}$ & Frequency & Percentage \\
\hline 1 & $40-51$ & 1 & $1.42 \%$ \\
\hline 2 & $52-63$ & 8 & $11.42 \%$ \\
\hline 3 & $64-75$ & 29 & $41.42 \%$ \\
\hline 4 & $76-87$ & 23 & $32.85 \%$ \\
\hline 5 & $88-100$ & 9 & $12.85 \%$ \\
\hline & Total & 70 & $100 \%$ \\
\hline
\end{tabular}

To assess reading comprehension used multiple choice test with four options A, B, C, and D, the number of item were 20. Students who answered right given score 5 , and 0 for wrong answer. There were $1.42 \%$ or 1 students who got interval score of $40-51,11.42 \%$ or 8 students who got interval score of $52-63,41.42 \%$ or 29 students who got interval score of $64-75,32.85 \%$ or 23 students who got interval score of $76-87$, and $12.85 \%$ or 9 students who got interval score of $88-100$ in reading comprehension achievement.

Table 6. Descriptive Statistics of Students' Reading Comprehension Achievement

\begin{tabular}{|l|l|}
\hline & $\begin{array}{c}\text { Reading } \\
\text { Comprehension }\end{array}$ \\
\hline Valid & 70 \\
Missing & 0 \\
Mean & 80.7143 \\
Std. Error of Mean & 1.51352 \\
Median & 80.0000 \\
Mode & 80.00 \\
Std. Deviation & 12.66302 \\
Variance & 160.352 \\
Range & 50.00 \\
Minimum & 50.00 \\
Maximum & 100.00 \\
Sum & 5650.00 \\
\hline
\end{tabular}


The researcher found that mean score of reading comprehension achievement was 80.71 and Median was 80.00 . Thus, Mode was 80, Variance was 160.352 . The Standard Deviation of the data was 12.663, Range was 50, the Minimum Score that students got was 50, and Maximum Score that students got was 100 . It can be inferred from the explanation above that students' understanding of reading is strong.

On the basis of research, the researcher used the SPSS 16 window-based program software to respond to the statistical hypothesis, and the researcher used multiple regressions and two ways to determine whether or not: (1) student interest was significantly influenced in the reading of SMP Negeri 32, Ogan Komering Ulu; (2) The reading habits of students at SMP Negeri 32 Ogan Komering Ulu had a substantial influence on their reading performance; (3) There was a major impact on reading habits at SMP Negeri 32 Ogan Komering Ulu among students' reading engagement and reading skills.

Measuring major impact on the reading performance of students' confidence in reading. This section, the researcher used the basic linear regression to figure out whether the interest in reading and the performance of understanding were significantly influenced. In the following table, the outcome of regression is shown:

Table 7. The Regression between Students' Reading Interest on Their Readiing Comprehension Achievement Summary

\begin{tabular}{|l|l|l|l|l|l|}
\hline Model & $\begin{array}{l}\text { Sum of } \\
\text { Squares }\end{array}$ & Df & $\begin{array}{l}\text { Mean } \\
\text { Square }\end{array}$ & F & Sig. \\
\hline Regression & 538.638 & 1 & 538.638 & 8.692 & $.004^{\mathrm{a}}$ \\
\hline Residual & 10.525 .647 & 68 & 154.789 & & \\
\hline Total & 11.064 .286 & 69 & & & \\
\hline
\end{tabular}

a. Predictors: (Constant), Result Reading Interest

b. Dependent Variable: Reading Comprehension

From the calculation, the researcher found that the value of F-count $=8.692>$ Ftable $=3.98$, implies, Ha has been accepted, $\mathrm{H} 0$ has been rejected and regression has been significant.
Measuring significant influence between students' reading habit on their reading comprehension achievement. The researcher continued to analyze the regression of students' reading habit on their reading comprehension achievement. The result of regression can be seen in the following table:

Table 8. The Regression between Students' Reading Habit on Their Reading Comprehension Achievement Summary

\begin{tabular}{|c|c|c|c|c|c|}
\multicolumn{7}{c|}{ ANOVA $^{\mathbf{b}}$} \\
\hline Model & $\begin{array}{c}\text { Sum of } \\
\text { Squares }\end{array}$ & Df & $\begin{array}{c}\text { Mean } \\
\text { Square }\end{array}$ & F & Sig. \\
\hline Regression & 5.503 .007 & 1 & 5.503 .007 & $\begin{array}{c}67.2 \\
87\end{array}$ & $\begin{array}{c}.000 \\
\text { a }\end{array}$ \\
\hline Residual & 5.561 .278 & 68 & 81.784 & & \\
\hline Total & 11.064 .286 & 69 & & & \\
\hline
\end{tabular}

a. Predictors: (Constant), Result Reading Habit

b. Dependent Variable: Reading Comprehension

From the calculation, the researcher found that the value of $F_{\text {count }}=67.287>F_{\text {table }}=3.98$ and it means that, Ha was accepted, $\mathrm{H}_{0}$ was rejected and the regression was significance.
Measuring significant interaction effect among students' reading interest and reading habit on their reading comprehension achievement. The researcher found out the influence of $\mathrm{X}_{1}, \mathrm{X}_{2}$, on $\mathrm{Y}$. Multiple regressions were used to calculate the regression on them. 
The result of calculation was presented in the following table:

Table 9. The Regression among Students' Reading Interest, Reading Habit, on their Reading Comprehension Achievement Summary

ANOVA $^{\mathbf{b}}$
\begin{tabular}{|l|l|l|l|l|l|}
\hline Model & $\begin{array}{l}\text { Sum of } \\
\text { Squares }\end{array}$ & Df & $\begin{array}{l}\text { Mean } \\
\text { Square }\end{array}$ & F & Sig. \\
\hline Regression & 5.560 .479 & 2 & $\# \# \# \#$ & $\# \# \#$ & $.000^{\mathrm{a}}$ \\
\hline Residual & 5.503 .807 & 67 & 82.146 & & \\
\hline Total & 11.064 .286 & 69 & & & \\
\hline
\end{tabular}

a. Predictors: (Constant), Result Reading Habit, Result Reading Interest

b. Dependent Variable: Reading Comprehension

The researcher has found in the table above that the F-count value $=33.845>$ Ftable $=3.98$. The results of this study have now proven that Ha has been accepted and $\mathrm{H} 0$ rejected. Ha said that students' interest in reading $\left(\mathrm{X}_{1}\right)$, habits of reading $\left(\mathrm{X}_{2}\right)$, and reading understanding have a major interaction impact (Y). Ha was approved. It can be inferred. The relationship between $\left(\mathrm{X}_{1}\right),\left(\mathrm{X}_{2}\right)$ and was important (Y).

\section{CONCLUSION}

The following inference can be taken from the results discussed in the previous chapter: 1) if students have a high level of interest in reading English, they can understand good English easily; 2) if students are well used to reading text and understanding the text easily, the skill of students to understand the word is also good; and 3 ) if they are interested in reading, they can understand and understand the word easily.

\section{REFERENCES}

[1] Genlott, A. A., \& Grönlund, Å. (2013). Improving literacy skills through learning reading by writing: The iWTR method presented and tested. Computers \& Education 67 98-104.

[2] Mulla, K.R. (2014). Information Literacy for Students and Teachers in Indian Context. PEARL A Journal of Library and Information Science, Vol. 8, No. 2: 88-96. DOI: 10.5958/09756922.2014.00728.1

[3] Jaleel, S., \& Thomas, A. M. (2019). Learning Styles: Theories and Implications for Teaching Learning. USA: Horizon Research Publishing.

[4] Obaidullah, M., \& Rahman. (2018). The impact of internet and social media on the habit of reading books: A case study in the Southern Region of
Bangladesh. Studies in English Language and Education, 3(1), 25-39.

[5] Apriani, E. (2016). A New Literacy: The Role of Technology to Develop Student's Character. Ta'dib: Journal of Islamic Education Volume 21, Number 1 .

[6] Cunningham, A. E, \& Stanovich, K. E. (2001). What reading does to the mind. Journal of Instruction, 1(2), 137-149.

[7] Huang, S., Capps, M., Blacklock, J., \& Garza, M. (2014). Reading habits of college students in the United States. Reading Psychology, 35, 437-467.

[8] Levine, L. E., Waite, B. M., \& Bowman, L L. (2007). Electronic media use, reading and academic distractibility in college youth. CyberPsychology \& Behavior, $\quad 10(14), \quad 560566 . \quad$ DOI: 10.1089/cpb.2007.9990.

[9] Balan, S., Katenga, J. E., \& Simon, A. (2019). Reading Habits and Their Influence on Academic Achievement Among Students at Asia Pacific. Abstract Proceedings International Scholars Conference Volume 7 Issue 1, pp. 1490-1516.

[10] Siregar, S. (2010). Statistik Deskriptif untuk Penelitian [Descriptive Statistics for Research]. Jakarta: PT Raja Grafindo Persada. 